\title{
The Capital Social in the Development of Banda Aceh City, Indonesia
}

\author{
Rahmalia $^{1^{*}} \quad$ Teuku Zulyadi $^{2}$ \\ 1.School of Journalism and Communication, Huazhong University of Science and Technology (HUST), Wuhan \\ 430074, Hubei Province, P. R. China \\ 2.College of Public Administration, Huazhong University of Science and Technology (HUST) \\ Wuhan 430074, Hubei Province, P. R. China
}

\begin{abstract}
The growth and development of Banda Aceh city has its own characteristics. One of the characteristics is Masjid (mosque) which is spread all around the city. Masjid's congregations are part of the city development's agents. This research depicts the social capital of Banda Aceh's people in the development of the city. The Qualitative method has been used in the research in order to gather information that is relevant to the research object. Generally, the research result depicts how the people in Banda Aceh city shape norms and networks which influence each other. Thus, people can trust each other for reliable city development's ideas. The capital social formed has become one of a productive asset to encourage economic development and the society sustainability. Poverty eradication and other social developments can be effectively encouraged through communication among people in the congregations. One of very significant moves is to connect these congregations to the city leaders and stakeholders.
\end{abstract}

Keywords: Masjid (mosque), capital social, society, development, Banda Aceh.

DOI: $10.7176 /$ RHSS/9-2-11

\section{Introduction}

The Aceh government has authorized the social welfare Qanun (local government regulation). The role of the local government as the responsible party in handling problems in Aceh province has been clearly mentioned in the regulation. One of the most important things in a local regulation is sufficient budget allocation to create an ideal condition, identical to what is stated in the Qanun.

The city of Banda Aceh is hundreds years old. Considering its history as one of the oldest cities in Indonesia, it is unfortunate that this capital city of Aceh province is still struggling with various issues. There are issues about law, economic, religion, and even social and governmental issues. The city government has claimed to commit in realizing Banda Aceh as a model of prosperous city in Indonesia and even the world. The ideal society were not simply an object of a concept of the Government. The people actively participated in the society development (as subject). It is the harmony between the people and the government which eventually creates good governance.

According to Kooiman, as cited by Maryono (2014), Governance is a series of the socio-political interaction process between government and society in various fields related to public interest and government intervention on those interests. Governance is a mechanism, a process and an institution through which citizens express their interests, mediate their differences and exercise their legal rights and obligations. Governance is a process where government's service agencies manage public resources and guarantee the human rights. In this context, good governance basically means free from abuse of power and corruption, also recognition of human rights based on lawful governmental system.

Implementation of the principle of good governance is a necessary condition to gain the trust of the society. The higher society participation in the development, the more these people trust their government. On the other hand, if corruption cases of high government officials are still all over the news, the people will surely lose their trust in the government. Community trust and government are requirements for the realization of social capital.

(Fukuyama 2002) believed that social capital plays a crucial role in maintaining the cohesion among the people and is a necessary component in social control. The essence of social capital is trust. Their trust for each other allow them to work together whether it is to achieve a goal, or to face a common threat which comes from outside or from inside.

(Robert 2004) explained that in its implementation, capital social is a collection of sources which are bound by family relationship, exist in community organizations and contribute to social and cognitive development of children and teenagers. Like any other investment, social investment is productive, which enables several achievements that are impossible to achieve without it.

Similar to physical and human investment, social investment is not entirely exchangeable, except for certain activities. Certain forms of social investments which are aimed to facilitate several actions may be useless or harmful for some other people. Unlike other forms of investment, social investment is attached to the structure of relationships between people and people. Social investment does not focus on individuals or any physical 
production tool.

\section{Research Statement}

Based on the background of the problem, the research statements of this study are:

a) Networks formed between the people in Banda Aceh.

b) Social capital as an investment of Banda Aceh societydevelopment.

\section{Research Methodology}

In regard to this writing, the writer chose the qualitative approach to gather relevant information about the object of research. Qualitative approach is an approach based on real situation and the experiences of the respondents, whose reference to the theory can eventually be found.

This study is aimed to find and describe social capital in carrying out development in Banda Aceh, Indonesia. A qualitative approach is a research where most of the data are presented in the form of words rather than a series of numbers. The data are collected through various kinds of observation and interview. Furthermore, the qualitative analysis still uses words, which are usually organized into extended text.

This research uses a qualitative approach for some reasons. First, it relies on the power of narrative or verbal explanation in describing the social capital. Second, the researcher tries to conduct research as it is, that is to avoid any kind of manipulation. Third, inductive analysis is used because the data retrieval is done through indepth interviews. The questions posed are also open, where the interviewees are free to answer the questions based on what he or she understands. All three reasons above are reinforced by (Patton's 1990) explanation that unique and ideal qualitative method consists of three parts: (1) qualitative data, (2) naturalistic inquiry, and (3) inductive or case-based content analysis.

\section{Society Development}

Society development (Zubaedi 2007) as an effort to develop a sustainable and active society condition based on the principles of social justice and mutual respect. Community workers facilitate citizens in the process of creating social justice and mutual respect through broad development programs that link all components of society. Society development has values of openness, equality, accountability, opportunity, choice, participation, mutual benefit, mutual reciprocity, and ongoing learning.

(Adi 2008) asserted that society development intervention model is an intervention model focusing on human aspect and society empowerment. There is a strong element of education in order to improve the society. Basically, this approach is very strongly influenced by opinions that develop the discourse about society, where the nature of welfare on the discourse is judged by the growth of citizens' participation. Citizen's participation in the process of society empowerment is one of the key to establish social welfare. Their participation, whether it is through physical participation, giving ideas, or giving financial donation, is expected to improve a sense of togetherness and a sense of belonging to the process and result in the community.

Ife, cited by (Indrajat et al. 2013) said that society development is actually a process. In evaluating a society development project, everyone must watch the process. Similarly, the society development planning and programming are both about the process; it is not the result that should be concerned about.

From all of the above experts' views, it can be concluded that society development is an effort to improve certain society's life through collective action. In general, society development covers planning, coordinating and developing various planning activities or community projects. As a collective action, society development involve several agents such as social workers, local community, charity and other concerned institutions who work together starting from planning, execution, until evaluation towards the programs or projects (Suharto 2009).

\section{Social Policy as Public Policy}

Social welfare development basically leads to development policy whose objective is to promote the quality of life or the standard of humans lives (Chamsyah 2009). Nevertheless, welfare development is not a single strategy to improve people's welfare. It is only one of other social policy strategies in order to achieve its objective. To execute it effectively, the social policy must be integrated with a conducive political system and macro-economy policy, including financial policy and orderly monetary with progressive and proportional taxing system.

Nowadays social policy is included into the coverage of public policy study, especially the public policies which influence people's welfare (Huda 2009). According to (Midgley 1995), to reach the standard of people's welfare, it is necessary to have a routine social program, whether it is conducted by local government or other social institutions. Broadly, social policy is executed in three categories, it is legislation, social service program and tax system.

Based on these categories, (Suharto 2009) stated that every legislation, law or local regulation concerning social lives and issues is a form of social policy, Regulation and legislation. Government has the authority to 
develop public policy which rule entrepreneurs, educational institutions, and private companies to adopt regulations which directly give impact towards people's welfare social service programs.

Most of the policies are executed and applied in the form of social services such as donation for necessities, financial support, expansion of opportunities, social protection and social guidance (counseling, advocacy, and guidance). Tax system is known as financial welfare. Besides its function as the main source of social policy funding, tax is also an instrument straightly aimed to achieve a fair income distribution.

\section{Social Capital}

Social capital is built when the relationship among people who experience change correspond to methods which facilitate certain actions. Acknowledgement and relationship among them have great influence towards social capital. Human capital facilitate productive activities, while social capital help establish networking and trust. For instance, a group whose members show credibility and trust each other will be able to do more than another equal group with no similar credibility and trust.

Norms that grow or are formed in a society have a very significant role in shaping a social capital. People do not need to worry about criminalities if the community holds onto the norms, because it can prevent a crime from happening. The norms which strengthened by social support, status, honor and other rewards is a capital social which encourage families and family members to dedicate themselves for their families. It will also encourage social development which grows out of small group of dedicated people who invite others to work for the sake of the community.

In some cases the norms are internalized. In some others, most of the norms are supported by external rewards towards dedication and unselfish actions. Nevertheless, whether it is supported by internal or external rewards and sanctions, the norms application is crucial for the good of the people. In some aspects, the shaping of the norms is a main transition from micro to macro, because the process arises from individual actions. The norm itself is on systematic level which affects further individual actions, whether it is the sanction applied by the incumbent, the norms, or actions following the norms. The norms and values incorporated in this definition can develop from simple norms between two colleagues to complex systems of values created by their respective beliefs.

Another problem concerning informal networks is a contradiction between the strong influence of these norms and values in connecting the community with its openness towards people, ideas and influences outside of the community. Therefore, the network that is understood as an informal ethical relation is connected with phenomena such as nepotism, favoritism, intolerance, and personal and nontransparent system. This network is as old as human itself, and in numerous aspects, it is dominant in most of social relationship of pre-modern society.

\section{Result and Discussion \\ Network among Society in Banda Aceh}

Aceh is dubbed as the Veranda of Mecca (Widianti 2006) because Islam first reached Indonesia through this westernmost region of Sumatra (Wulandari et al. 2017). As the name implies, the majority of Acehnese are Muslims, and their daily life is largely influenced by Islamic teachings. Therefore, the Ulama (the Muslim scholars) and leaders are one of the most important part of the people's life.

Historically, the development of scientific knowledge of the Acehnese people is inseparable from the presence of masjid as a representational space (Gale 2004). Masjid is not merely a place for worship, but also a place where people gather to learn and discuss Islamic teachings (Adil et al. 2013). The gampong (village) forum which involves all community elements is also conducted in masjid. The status is strengthened by the appellation of 'Imum Mukim' (Imum: Arabic for leader, Mukim: Arabic for residency) for the leader of several gampongs. The appellation of "Imum" explains that for Acehnese people, the leadership and the Islamic teachings cannot be separated.

Regulation number 25 year 2004 about National Development Planning (UU No. 25 2004) Regulation number 32 year 2004 about Local Government (UU No. 32 2004) and Government Regulation number 72 year 2005 about Village (UU No.72 2005), all provide opportunities to villages to arrange a more participatory development planning and budgeting and which is based on the village needs, it is best to utilize this opportunity as optimal as possible.

The development planning and budgeting at village level, as has been conducted so far, has not shown an ideal process and results. In the process, not all village elements are involved. Meanwhile in the results, the formulation of wants and needs is often not well separated. Besides, the results of village development planning discussion rarely accommodate people's needs, especially the poor ones.

Development planning meetings (Musrenbang) at the village to district level are one of the tools currently available in the development planning system at the national level. It is time for Masjid as a worship facility for the people (Hussin et al. 2012), which is sheltered by the state, to accommodate the meetings as a way to solve 
the problems of the public, such as poverty and low access to education and health.

Masjid is a place for worship for Muslims. In practice, Masjid is also a place for the people to discuss and find solutions to the problems of the society, both economic and socio-political problems. The position of the mosque which is aspirational towards the problems of the people needs to be re-implemented. It is time for the community to accommodate the people's problems and find solution together.

To be productively involved in the development planning meetings, Takmir (Masjid leaders) need to be equipped with knowledge and skills. Therefore, a training on Opportunities for Masjid Community Involvement was held in the gampong development planning meetings. Some of the material presented and discussed in the training is expected to be sufficient to accommodate Takmir to be involved at least in the gampong development planning meetings (Musrenbang). In implementing community development, each network needs to gather to provide input and ideas for the realization of a just and equal society order.

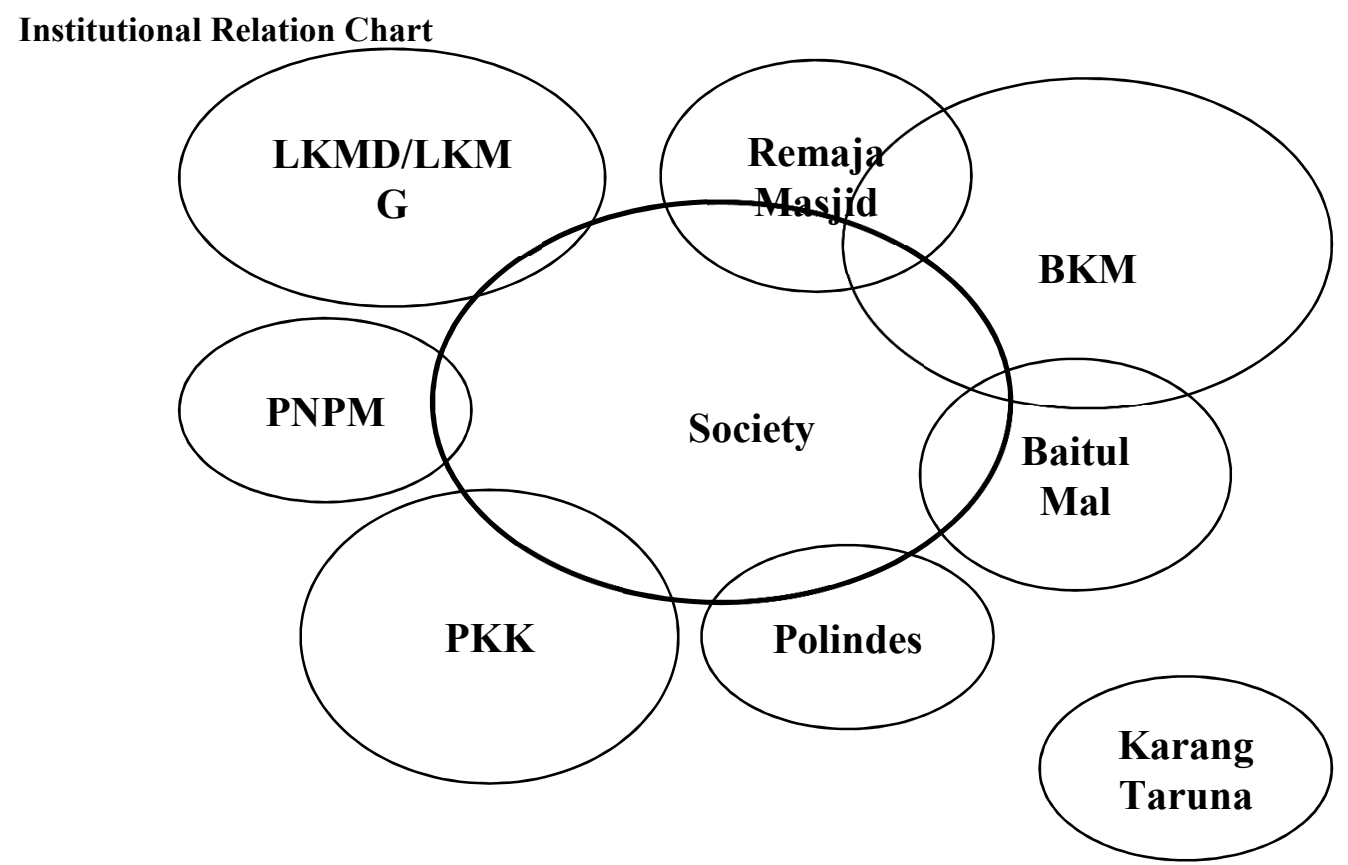

Source: Authors, 2017.

Figure 1: Society Networking

\section{Activities in Masjid as the Social Capital for the Development of Banda Aceh}

Gampong (village) development planning meetings are held to propose programs that fulfill the basic rights of communities such as poverty alleviation, health and education. However, there has been no realization, even though it has followed technical guidelines. Village budgets are used to build fish ponds, provide medicines at community health centres (Puskesmas), integrated service posts (Posyandu) and fogging.

Proposed education programs are top-down and handled directly by the government, because this concerns the national program. The infrastructure development in Banda Aceh is already good because the development does not only focus on physical development, but more on non-physical such as poverty alleviation programs or community empowerment activities.

There are proposed programs from the community during development planning meetings, but there has been no realization by the government. The programs proposed by the community through the meetings are mostly in the physical field, rarely propose non-physical ones. However, a lot of physical developments have been fulfilled for gampongs in Banda Aceh. Also, there are many programs that community plan during the gampong development planning meetings that are rarely approved by the government (Ismail 2017).

Activities in Masjid, in the form of congregational prayers, Qur'an (the Islamic holy book) learning and recitation, and Islamic holidays are actively and well carried out. Social activities in the form of mutual cooperation, visiting sick people with certain conditions are also spearheaded by Masjid. A lot of affairs are also settled in Masjid, depending on the problems. There are people who violate existing ethics, and some solutions have been taken to solve this, such as discussion with the youth (Yahya 2017).

Until now, the representatives who come to the development planning meetings are mostly public figures (Ismail, 2014). The representatives come to give input and suggestions. Previously, they came personally, not to represent their community. Development planning meetings are always held every year, but the people 
themselves say that the meetings are not needed, because there is no realization of the programs, such as the provision of fences, Masjid equipment, and the provision of river embankments that have not been realized until now (Rasyidah 2017).

For health programs in the previous year there were physical development plans such as rehabilitation of integrated service posts. It was a non-physical proposal from the Women's Action Plan Meetings (Musrena), because the Musrenbang itself was attended by participants from the Women's Action Plan Meetings. Then the data was implemented for 2014 (Rusli 2017).

The proposed programs are commonly urgent ones, because the government observes programs that are needed by the community, to be realized later. The government also provides scholarships, but only certain people can actually obtain the scholarship. Programs needed by the community are prioritized, so they would be approved by the government. All the proposed programs reach the government, but only urgent and needed programs would be realized.

People often consider that funding in the form of money will be used unproductively, but funding for physical development can be used for labor intensive programs, so that it can accommodate more labors. If the funds are used for capital money, it is usually difficult to get the money back after. People often think of why they should return the money when the government alone does a lot of corruption. So money is not traceable, it is better to give physical funding, because it can accommodate labor that will create jobs, one way to reduce unemployment.

Communication and relation of gampong officials and Masjid administrators in village development planning must be good. They must cooperate with each other because people who work in the Keuchik (village head) office are also active in Masjid, so these people are involved in the same activities. The presence and involvement of Masjid community in the gampong meetings are still less active, because the results of the meeting are often unrealized. Masjid community gives their support in gampong development planning by providing inputs instead of physical support.

The involvement of the Masjid community has not been optimal is also because the community does not really understand the role of Masjid. Until now Masjid is only used for worship. It would be better if the existing budget was developed, people would remember that the budget is a community fund, so they would automatically remember that it is a deposit. We must focus on learning about social affairs, namely community empowerment.

During this time, the mosque was used by the community as a place of complaint. Meanwhile, the management does not have the capacity to solve it. For example, someone complained that there was no rice, but the mosque did not know how to solve the problem of people who did not have the rice. In this context, mosque administrators must explore the development of the community so that there is an increase in their capacity in resolving social problems, both in terms of economic, social, and in terms of worship.

\section{Conclusion}

Social development is a human-centered concept of development. Meanwhile, social capital is a relationship formed in society in the form of networks, norms and beliefs. This is very important for a country that aspires to the welfare of its people. The better the social capital of an area, the better the development in the area will be.

Banda Aceh is one of the cities that aspire to the development of community welfare. Therefore, the development budget is also allocated to create social capital from the community itself. This can be seen from the ideas of development born from efforts to solve social problems. The welfare agenda that is raised must be an enchanter and driver for social capital.

Masjid that function as the centre of community activities are the right means to create social capital. With the birth of ideas from Masjid development, there will be high trust between the community, the government and all stakeholders. Physical development must go hand in hand with social development, this is where the importance of strengthening norms, networks and trust from the community come.

\section{References}

Adi, I.R., 2008. Intervensi komunitas: Pengembangan masyarakat sebagai upaya pemberdayaan masyarakat. Rajawali Pers (Rajagrafindo Persada).

Adil, M.A.M., Mohd-Sanusi, Z., Jaafar, N.A., Khalid, M.M. and Aziz, A.A., 2013. Financial Management Practices of Mosques in Malaysia. GJAT, 3(1), pp.23-29.

Chamsyah, B., 2009. Reinventing pembangunan sosial untuk kesejahteraan masyarakat Indonesia. Trisakti University Press.

Fukuyama, F., 2002. Social capital and development: The coming agenda. SAIS review, 22(1), pp.23-37.

Gale, R., 2004. The multicultural city and the politics of religious architecture: Urban planning, mosques and meaning-making in Birmingham, UK. Built Environment, 30(1), pp.30-44.

Huda, M., 2009. Pekerjaan sosial \& kesejahteraan sosial: sebuah pengantar. Pustaka Pelajar. 
Hussin, M.Y.M., Muhammad, F., Razak, A.A., Habidin, N.F., Mohamad, S.I.S. and dan Ekonomi, F.P., 2012. Eksplorasi Dana Kewangan Masjid di Negeri Perak. Prosiding Persidangan Kebangsaan Ekonomi Malaysia ke VII (PERKEM VII) Transformasi Ekonomi Dan Sosial Ke Arah Negara Maju) Ipoh, Perak, 2, pp.1274-1286.

Indrajat, H., Budihardjo, B., Hadi, I. and Budiono, P., 2013. Partisipasi Masyarakat Dalam Proses Pembangunan di Kecamatan Kemiling. PROSIDING PENELITIAN FISIP UNILA.

Midgley, J., 1995. Pembangunan sosial: Perspektif pembangunan dalam kesejahteraan sosial. Direktorat Perguruan Tinggi Agama Islam.

Patton, M.Q., 1990. Qualitative evaluation and research methods. SAGE Publications, inc.

Puspaningrum, I.I. and Maryono, A.H., 2014. Peran kepala desa dalam mewujudkan tata kelola pemerintahan yang baik (Studi Di Desa Gunggung Kecamatan Batuan Sumenep). PUBLIC CORNER, 6(2).

Lawang, R.M., 2004. Kapital sosial dalam perspektif sosiologik: Suatu pengantar. Fakultas Ilmu Sosial dan Ilmu Politik, Universitas Indonesia (FISIP UI) Press.

Mufizar, M., 2012. Pembangunan Sosial Masyarakat Perbatasan Di Kecamatan Sajingan Besar Kabupaten Sambas Provinsi Kalimantan Barat. JPMIS.

Widianti, E.T.R., 2006. The Ulama in Aceh in Time of Conflict, Tsunami and Peace Process: An Ethnographic Approach(Doctoral dissertation, Ohio University).

Wulandari, E., Soetomo, S., Syahbana, J.A. and Manaf, A., 2017. The Ecology Character of Banda Aceh City in the 17th Century. Journal of Islamic Architecture, 4(3), pp.93-101.

Zubaedi., 2007. Wacana Pembangunan Alternatif. Jogjakarta: Ar-Ruzz Media.

Ismail Muhammad, Masjid Congregation in Banda Aceh, 16 July 2017.

Yahya, Masjid Administrator in Banda Aceh, 20 July 2017.

Rasyidah, Masjid Congregation in Banda Aceh, 27 July 2017.

Rusli Ahmad, Masjid Activist in Banda Aceh, 27 July 2017

Indonesian Government. (2017). Undang-undang Nomor 25 Tahun 2004 tentang Sistem Perencanaan Pembangunan Nasional (Regulation number 25 year 2004 about National Development Planning), retrieved from:https://www.bappenas.go.id/id/data-dan-informasi-utama/produk-hukum-peraturanperundangan/undang-undang/uu-no25-tahun-2004-tentang-sistem-perencanaan-pembangunan-nasionalsppn (accessed 15 August 2017).

Indonesian Government. (2017). Undang-undang Nomor 32 Tahun 2004 tentang Pemerintah Daerah (Regulation number 32 year 2004 about local government), retrieved from: http://www.dpr.go.id/dokjdih/document/uu/33.pdf (accessed 15 August 2017).

Indonesian Government. (2017). Peraturan Pemerintah Nomor 72 Tahun 2005 tentang Desa (Government Regulation number 72 year 2005 about village), retrieved from: https://www.bphn.go.id/data/documents/05pp072.pdf (accessed 15 August 2017). 